\title{
Surface Water-Groundwater Interactions and Bank Storage during Flooding: A Review
}

\author{
Gadadhara Ferraz $^{1 *}$, Tamás Krámer ${ }^{1}$ \\ ${ }^{1}$ Department of Hydraulic and Water Resources, Faculty of Civil Engineering, Budapest University of Technology and Economics, \\ Múegyetem rkp. 3, 1111, Budapest, Hungary \\ * Corresponding author, e-mail: gadadhara.ferraz@emk.bme.hu
}

Received: 18 May 2021, Accepted: 19 September 2021, Published online: 05 October 2021

\begin{abstract}
The interaction between river floods and groundwater not only replenishes groundwater resources, but also contributes to the attenuation of flood waves and is therefore a hydrologic factor in flood risk management. The magnitude of this interaction is expressed as bank storage, that is, the volume of the surface water that is temporarily stored in the riverbanks and slowly released back into the river after the peak of the flood wave. The amount of bank storage depends not only on the hydrograph of the river, but also on the morphology and hydrogeology of the river valley. This article offers a review of the current understanding and description of water exchange between the river and aquifer, with a focus on exchange due to flood events. The main field measurement methods of river-aquifer interactions, made to determine the properties of the aquifer, are summarized. The foundations of mathematical models are also reviewed, centered on how the surface and groundwater flow models are coupled, as well as on dimensional and process-related simplifications.
\end{abstract}

Keywords

flood, river-aquifer interactions, bank storage, modelling, field measurements

\section{Introduction}

The importance of considering surface water and groundwater as a single resource, and not as separate entities, is the basis of integrated water resources management, e.g., Winter et al. [1] state that "Management of one component of the hydrologic system, such as a stream or aquifer, commonly is only partly effective because each hydrologic component is in continuous interaction with other components.". Numerous studies and review papers focus on the interaction between surface water and groundwater, including recent ones [2-5]. Many researchers reported on the exchange of water in the hyporheic zone, induced by seasonal changes in surface water level and groundwater level (e.g., [3, 6-8]). However, surface and groundwater exchanges induced by major flood events are different from those induced by seasonal changes in river stages [9]. In fluvial environments, pluvial floods can occur by rapidly rising of surface water level. On some occasions, the level of surface water may exit onto the floodplain, causing surface water to infiltrate vertically and horizontally into groundwater (e.g., $[10,11])$. The water stored in the banks, called bank storage, will return to the river after the flood wave passes [12-14]. The amount of bank storage will depend on parameters such as duration, height, and format of the flood hydrograph, and the transmissivity and storage capacity of the aquifer $[15,16]$.

River-aquifer interactions were documented first by hydrologists and then by ecologists, as they began to recognize the importance of these exchanges for the biota and metabolism of lotic ecosystems [4]. The consequences of these exchanges in terms of water quality and ecological processes will not be addressed in this article, since the main objective of this review is the quantitative aspects. For a comprehensive review of recent studies that focus on the ecological and qualitative aspects of river-aquifer interactions, we refer to $[3,4,7]$.

To quantify the exchanges between groundwater and surface water, a variety of techniques is addressed by water managers in water resources, depending on the objective of the study [17]. Instruments of field monitoring include wells, piezometers, pluviometers, fluviometers, surface water level gauges, among others, for different spatial and temporal scales [18]. Tracing techniques have been widely 
used to characterize flow paths and estimate groundwater flows [19], and can be used to estimate fluxes in smallscale exchanges, such as hyporheic exchanges [20], as well as in a river reach [21]. For a regional scale (e.g., catchment scale), the use of flow network modeling and analysis is recommended (e.g., [22-24]).

As the universal analysis method, the space-time responses of surface-groundwater exchanges and bank storage due to flood events are quantified by numerical or analytical models. Many researchers have put forward analytical solutions that describe and quantify the water movement between surface and groundwater (e.g., [9, 12, 15, 25-34]). Numerical flow models can also simulate the highly complex movement of the water for bank storage in the alluvial aquifer (e.g., [10, 11, 16, 35-40]). Most of the cited studies resolve only the transverse dimension and therefore, do not consider groundwater movement parallel to the river, disregarding, then, the fact that large flood events commonly result in a diffusive flood wave traveling in the river channels, in which the peak of the river stage attenuates with the travel distance downstream [41]. The diffusive flood wave will result in a groundwater flow component parallel to the river channel. The responses of groundwater flow in directions perpendicular and parallel to the river are demonstrated through modelling in studies such as $[9,28,30]$, for example.

The goal of this review paper is to present the current level of understanding of river-aquifer interactions, assisting in managing the dynamics of surface water. The paper summarizes the current state of knowledge of the exchange processes between surface water and groundwater, focusing on the effects of these interactions during river floods, linking flood hydrograph and aquifer properties to the dynamics of bank storage, and summarizing experiences of field monitoring as well as analytical and numerical modeling.

\section{Surface water and groundwater interactions in floodplains}

River reaches are commonly described according to the type of hydraulic connection and flows between the river and the aquifer [1]. Flow paths can occur either from the water table to the river (=gaining or effluent river reach), or from the river to the water table (=losing or influent river reach) [2]. The direction of the flow is provided by the piezometric gradient [17]: in a gaining reach, the groundwater level is higher than the river level (Fig. 1(a)).
Conversely, a losing reach occurs when the river level is higher than the groundwater levels, i.e., the piezometric gradient is oriented from the river to the aquifer (Fig. 1(b)). During a flood, the river behaves as a losing reach in the rising limb, and as a gaining reach in the falling limb [8, 14]. For this to happen, the river must be hydraulically connected with the aquifer, which means that the water table must intersects the river's streambed [42]. If the river is hydraulically disconnected, an unsaturated zone exists between the streambed and the water table [43] (Fig. 1(c)). In this case, the river reach is classified uniformly as a losing river reach [1]. If groundwater levels are different between the two riverbanks, a flow-through river path is formed (Fig. 1(d)). When the river level is equal
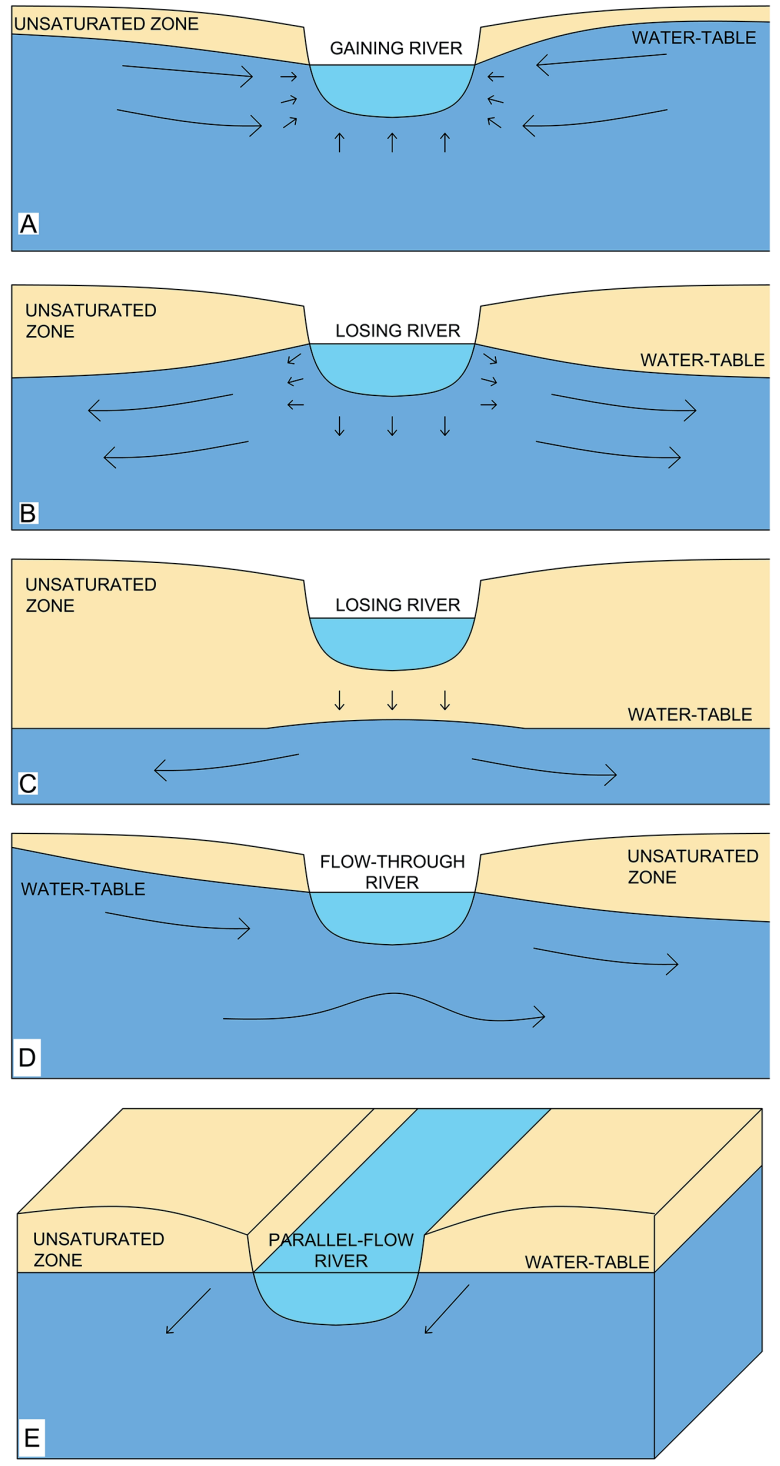

Fig. 1 Groundwater and surface water interactions: (a) Gaining and (b) Losing hydraulic connected reach; (c) Losing hydraulic disconnected reach; (d) Flow-through reach; (e) Parallel-flow reach 
to the water table level, the river is called a parallel-flow (Fig. 1(e)) and in this case no large-scale exchange would occur between river and aquifer [2].

In terms of a long timescale, a river may change from effluent to influent across its length depending on the crossed geological formations and on the flow regime [44]. In case of perennial, intermittent, or ephemeral rivers, discharge conditions depend on the regularity of baseflow, which, in turn, is determined by the groundwater level [45].

When overbank floods occur, water can infiltrate across the floodplain surface, under ponded waters even after floodplain flow has receded. In case of in-bank flood events, infiltration is constrained to the smaller bed surface. After the flood ends, with the drop in river water levels, the hydraulic gradient and a water flow is oriented from the alluvium back to the channel [11], which ends up maintaining the baseflow (e.g., [13, 14]). It was noted that the response of the floodplain during large overbank flood events showed that floodplain hydrology is predominantly a two-dimensional (in the vertical plane) process, with infiltration occurring in the vertical (mainly across the floodplain) and horizontal (near the riverbanks) direction. A down-reach component parallel to the river makes the infiltration three dimensional [10]. Fig. 2 shows the seepage from the river to the aquifer during floods events. The volume of water stored in the alluvium and released after the flood is called bank storage and is considered a significant hydrological process for flood management. Notably, bank storage can beneficially mitigate flood waves in a river that has permeable riverbed materials [28, 35], but the raised groundwater table can also cause damage in hollow underground structures and along flood protection levees.

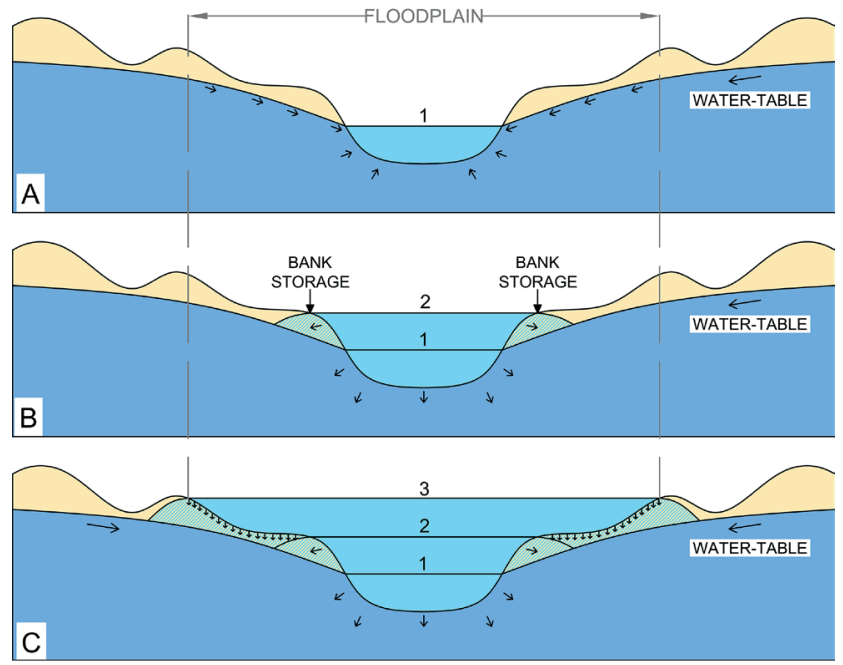

Fig. 2 Seepage from the river to the aquifer due to rise of river water level: 1) initial river level; 2) river level in-bank; 3) river level overbank
Exchanges between rivers and aquifers can occur on small spatial scales such as in the hyporheic zone (Fig. 3). The subsurface zone where river water infiltrates through short lengths of its adjacent bed and banks is called hyporheic zone [1]. The size and geometry of hyporheic zones vary significantly in time and space. The exchange between groundwater and surface water in the hyporheic zone makes its chemical and biological characteristics different from adjacent surface water and groundwater [1]. A longitudinal mass exchange occurs through the hyporheic zone when the river loses water by infiltration at a certain section upstream, and gains water at a certain section downstream, and vice versa. Various aspects of the hyporheic zone have been reviewed by researchers, such as [3] and [6]. Several important ecological aspects (e.g., nutrient rates, aquatic organisms, biodiversity) are based on hyporheic exchanges [7]. Groundwater models can be used to estimate the magnitude of hyporheic flows [8]. For example, the effects of floods on the hyporheic zone in a mountain river network were studied [33]. The travel times of hyporheic groundwater were analyzed using time series of electrical conductivity [46]. Bank filtration performance during 'drought' and 'flood' climate scenarios was also investigated [47].

\section{Bank storage response to a flood hydrograph and aquifer properties}

The volume of bank storage depends on duration, height, and shape of the flood hydrograph, on the transmissivity and storage capacity of the aquifer (e.g., [4, 5]), as well as the topography/morphology of the river valley (e.g., [21]). Knowing this, the influence of the geometry of the flood hydrograph in the discharge and bank storage was demonstrated by [15]. There is high variability in the shapes of the river stage hydrographs, owing to the diversity of drainage basin characteristics, the distribution of the rainfall and the discharge rating curve of the river at a given section, see e.g., [12]. For example, for a sharper rise of flood levels, which is characterized by a lower ratio of concentration-time (tc) to flood duration (Td), infiltration rate

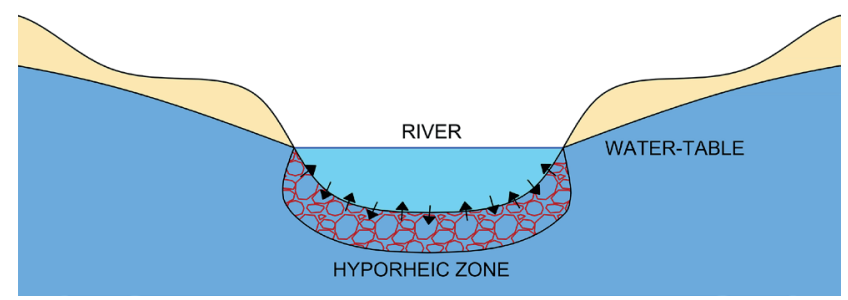

Fig. 3 Exchange flow through smaller areas (e.g., hyporheic zone) 
increases (Fig. 4(b)), and consequently, a larger volume of water is infiltrated in the aquifer. However, the volume stored (Fig. 4(c)) in the riverbanks is lower because of a short rising time (Fig. 4(a)) [15].

Another important characteristic that influences bank storage capacity is the hydraulic properties of the aquifer. At a given distance from the river, the groundwater level increases with increasing values of aquifer diffusivity (i.e., the ratio of transmissivity to storage) [15]. As expected, for higher values of aquifer diffusivity, wave propagation into the aquifer is faster (e.g., [9]), bringing the groundwater peak occurrence to an earlier time (Fig. 5(a)). On the other hand, the discharge (Fig. 5(b)) and bank storage volume (Fig. 5(c)) decreases with increasing aquifer diffusivity, since a higher value of aquifer diffusivity corresponds to a lower storage coefficient of the aquifer for a fixed value of transmissivity. In the absence of direct field measurements, aquifer diffusivity can be determined through analytical and numerical modelling [48]. It is common to assume aquifer diffusivity to be stationary at a local scale regardless of hydromorphological conditions [49].

Nevertheless, if we increase transmissivity values and fix diffusivity in a model, then discharge (Fig. 6(b)) and
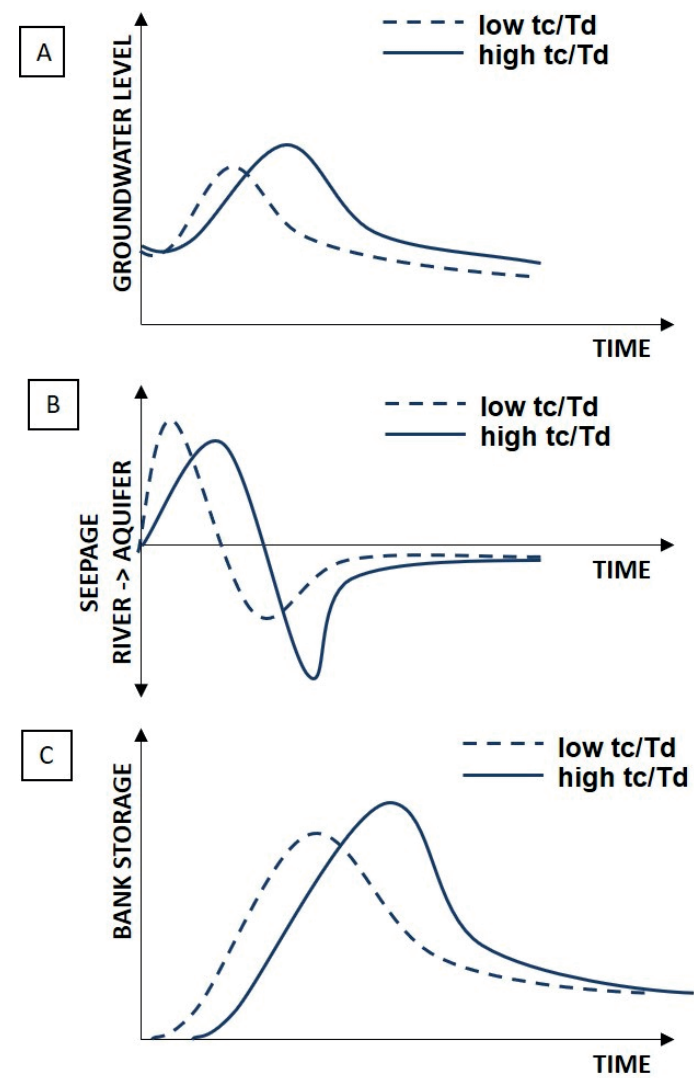

Fig. 4 Aquifer response for a flood hydrograph: (a) Groundwater level; (b) Seepage between river and aquifer; (c) Bank storage bank storage volume (Fig. 6(c)) increases as well [15]. Note that the groundwater level is unchanged; since it is a function of aquifer diffusivity, and not of transmissivity (Fig. 6(a)). On that account, in rivers with a coarse alluvium, i.e., with high aquifer transmissivity, the discharge associated with bank storage increases [14]. The transmissivity set in a model must reflect the properties of the soil, and so will be influenced by the hydraulic conductivity of both the riverbed and the aquifer [50]. In-situ measurement methods can be used to determine the hydraulic conductivity of the streambed (e.g., [17, 51, 52]). However, these approaches are challenging due to heterogeneity and the problem of integrating measurements at various scales [3]. The hydraulic conductivity values derived from the model calibration have a more conservative range than those of laboratory and field measurements [53]. Recently, integrated surface and groundwater models were developed to determine spatial variations in hydraulic conductivity across a river reach (e.g., $[54,55])$.

The presence of riverine vegetation can increase the rate of potential evapotranspiration, and, therefore, decrease the groundwater levels [52]. For a higher potential evapotranspiration rate, slightly more river water can infiltrate

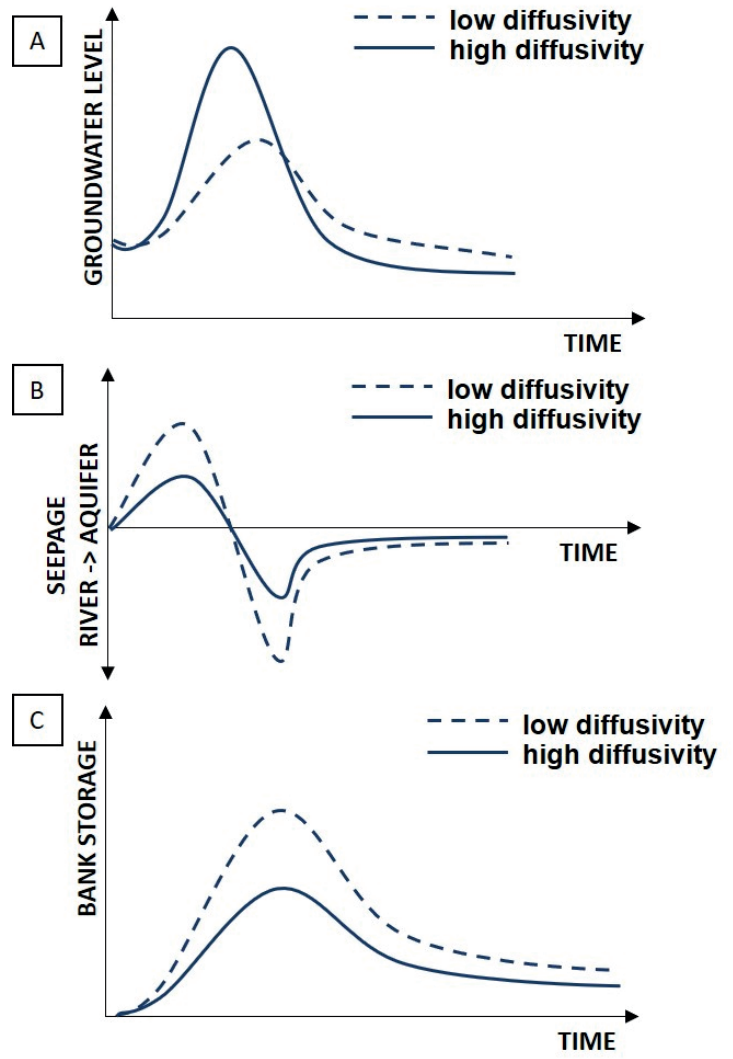

Fig. 5 Aquifer response for various aquifer diffusivities: (a) Groundwater level; (b) Seepage between river and aquifer; (c) Bank storage 


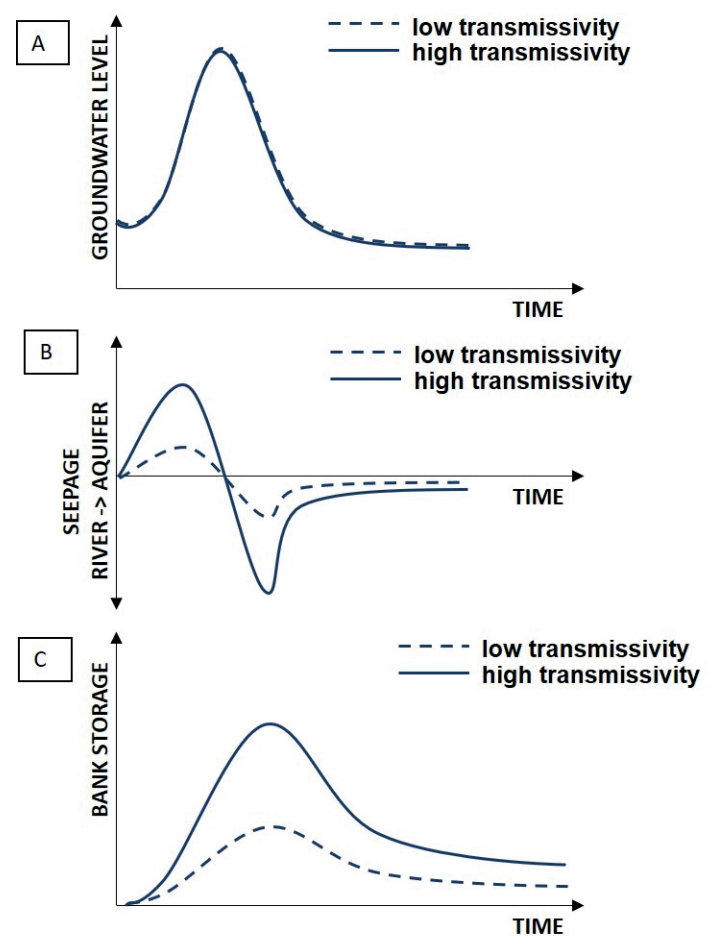

Fig. 6 Aquifer response for high and low aquifer transmissivities: (a) Groundwater level; (b) Seepage between river and aquifer; (c) Bank storage

into the aquifer, but also more bank storage is lost to evapotranspiration [16]. Although these losses are usually considered small, if a longer reach is considered or if the reach is relatively far upstream, then the contribution from hydrological processes such as evapotranspiration could potentially be significant [56]. In the case of flash floods (i.e., when there is a sudden, short-duration hydrological response in a river, regardless of the structure of the rain event or any process generated by the surface flow), the duration of a flood is short enough to neglect evaporation processes [54].

In summary, studies have shown the dependence of surface and groundwater interactions on parameters such as flood hydrograph and aquifer properties, to quantify groundwater levels, infiltration between river and aquifer and amount of bank storage. And to determine these parameters, field monitoring must be done, which includes hydrological measurements, such as surface water level and water table monitoring, and soil samples to determine aquifer properties.

\section{Field monitoring}

As reflected by the high number of case studies related to the interaction between surface water and groundwater, the need for methods to describe and quantify this flow is evident. Choosing the best method will depend on the physical and hydrological conditions present in the case study, as well as the interaction scale. A review of methods and techniques available to quantify the flow between surface water and groundwater can be found in [18] and [17]. In addition, [5] compare the relative magnitudes of the hyporheic exchange, river-aquifer exchange, and bank storage exchange in more than fifty papers.

For small spatial scales, survey of reaches with an extent of tens to hundreds of meters, methods such as seepage meters, "minipiezometers" or hydraulic potentiomanometers, piezometers, may be most appropriate [18]. Seepage meters provide a useful and inexpensive method of measuring infiltration flow through unconsolidated sediments in lakes, reservoirs, and rivers [55]. However, to obtain representative average seepage fluxes, measurements at many locations are required [17]. Piezometers provide point measurements of hydraulic head, which allows a detailed survey of the heterogeneity of flow conditions in the aquifer [17]. Therefore, all hydraulic head measurements must be taken at approximately the same time, and the resulting contour and flow maps are representative of that specific time only [1].

Additionally, tracing techniques have been widely used to characterize flow paths and estimate groundwater flow rates [19]. Applied methods include releasing of a nonreactive tracer at a point in the river reach and measuring its concentration over time at another point downstream (e.g., [21]). The tracer can also be released in a well, however, the release and the observation wells must be located close to each other due to groundwater velocities being small [17]. Physical properties of the water, such as temperature, can also be used as a tracer (e.g., [20, 57, 58]). Groundwater temperatures are relatively stable throughout the year, while stream temperatures vary strongly on a daily and seasonal basis [17]. Therefore, in gaining river reaches, sediment temperature and river temperature are markedly different, and in losing river reaches, the diurnal fluctuations of temperature in the river are reflected more strongly in the sediment temperature [1].

At a larger spatial scale, in the order of meters to kilometers of reach length, methods of analysis include surface flow modelling, groundwater flow modelling, and flow-net analysis, which consists of elaborating groundwater level contour maps with river water surface elevation and making assumptions about the aquifer properties and geometry [5]. Groundwater contour maps provide information about the direction of groundwater flow (e.g., gaining and/ 
or losing river) and the groundwater flow rate is estimated using Darcy's law. However, the determination of groundwater flow requires information on the hydraulic gradient and hydraulic conductivity of the aquifer [17]. Also, flow measurements can be used to estimate river-aquifer interaction at a larger scale, through river loss or gain depending on the differences in river flow between upstream and downstream locations (e.g., [22]). Determining groundwater discharge rate, location and chemistry from river sampling will be particularly accurate under the near-stationary conditions of low river flow. For transient conditions, river sampling should be carried out within a short period of time after the flow wave has passed and conservative tracers are targeted [22]. The same approach is used in measuring chemical longitudinal river sampling, and applying a mass balance methodology, if the chemical composition of groundwater is different from the river's (e.g., [23, 24]). One of the advantages of tracer methods over methods of flow measurement is that tracer methods are more sensitive to low groundwater inflow rates [50]. Although sequential flow measurement can determine net groundwater inflows (inflow minus outflow), chemical tracer methods provide information about gross groundwater inflows. Therefore, their joint use should allow net groundwater inflows to be divided into gross inflows and outflows [59]. The combination of flow measurement and tracer methods should therefore provide information on inputs and outputs and is the only method that can provide this information at the large scales required by water resource managers [59].

The measurements of the bank storage exchange flows are inferred based on the hydraulic head in observation wells near the river and the application of Darcy's law (e.g., [29]). The vertical and lateral extent of the bank storage and the exchange flow, due to the rise in the river, can also be determined by measuring changes in solute concentrations in wells near the river and modelling, as was provided by [49], for example. This estimate is based on the proportion of travel times, which is insensitive to the variation in hydraulic conductivity and is applicable to rivers with relatively steep slopes, small regional hydraulic gradients, and where rapid, large, and discrete flow events occur [49].

The main data collected as part of a typical monitoring routine are the groundwater and surface water levels provided by monitoring wells or piezometers installed overland on the river valleys, and gauging stations installed on the river, respectively. With these two data sources, exchanges are usually calculated using methods based on
Darcy's law. Additional rainfall data can be used. Csoma and Gálos [60] evaluate the levels of the Danube River, the water table from wells located in the region, and the precipitation data, focusing on the effects of buildings with deep foundations. Their results show that the groundwater flow is influenced by the river regime and by precipitation, especially in periods of prolonged drought, but very rapid river pulses can hardly be recognized at the wells.

In floodplain environments, studies were carried out to document hydrological interactions between river stage and groundwater level at a small scale (e.g., [61]). The propagation of pressure waves across floodplains was documented by $[31,61,62]$. The effect of variations in the river stage can be reflected in groundwater level at locations away from the river, as it is shown in [31, 61, 63].

There is usually a lack of data with high spatial and temporal resolution on the dynamics of the floodplain hydrology during flood events [64]. Wang et al. [65], for example, collected groundwater levels from 20 wells across the Sanjiang Plain, for five years, with a time interval of one month. Meanwhile, researchers such as Jung et al. [64], analyzed piezometric data with high temporal resolution, $15 \mathrm{~min}$ and 1 hour, respectively, during the period of one year, for the floodplain of the River Severn, England. In spite of some distinctive, research-oriented field campaigns, high spatial resolution is still a concern in studies, as field instrumentation generally covers only a limited part of the floodplain with piezometer transects [52, 64].

During extreme overbank flood events, only a few studies focused on accompanying hydrological processes (e.g., [10, 31, 66-68]) based on observed data from piezometer and river stages. Additionally, techniques using heat as tracer to quantify stream bed fluxes for extreme hydrologic events was used by Barlow and Coupe [63], demonstrating the ability to restrict bed water flow estimates and critical flow reversal stages, with little data available on groundwater levels. Note that extreme flood events can rarely be captured using dedicated field surveys due to the low probability of occurrence and the demand for time to prepare for a flood-triggered deployment, so modeling, rather than field measurements, is the universal method of analysis for bank storage during such events. This will be reviewed in the next section.

\section{Modelling studies}

Quantifying water exchange between groundwater and a transient open water body is an important task in many environmental and water resource applications. The 
movement of surface and groundwater, and consequently, its bank storage, can be described by means of analytical and numerical flow models. Analytical solutions that describe and quantify the movement of water in the riverbanks and the accompanying mass exchange between surface and groundwater have been proposed by many researchers (e.g., [12, 25-28]). On the other hand, numerical flow models have also been used for many decades to simulate the highly complex movement of water for bank storage in the alluvial aquifer (e.g., [16, 35, 36]). In this section, we review some relevant works to present the state of the art regarding analytical and numerical modelling of fluxes between rivers and groundwater, with special interest to bank storage and its importance during floods.

Several analytical solutions have been published for evaluating surface and groundwater interactions. These solutions are useful for understanding the physical processes in a groundwater flow system, for predicting shortterm water table fluctuations in response to a transient flood wave, the flow of water between the aquifer and the river, the accumulated bank storage, and for determining the hydraulic properties of the aquifer [69]. The solutions for surface and groundwater interactions are derived from Darcy's law and the law of conservation of mass (continuity equation), which states that the net rate of fluid mass flow into any elemental volume of aquifer is equal to the time rate of change of fluid mass storage within the element. The solutions are determined by defining a specific set of boundary and initial conditions [66].

The common assumptions before modeling surface and groundwater interaction problems, assumed by several researchers are: the alluvial aquifer is homogeneous, isotropic and of finite extent (e.g., [66, 67]); the aquifer's bottom is horizontal and impermeable (e.g., [9, 70]); the Dupuit-Forchheimer conditions are valid, namely: (a) in any vertical section the groundwater flow is horizontal; (b) the velocity profile is uniform along the depth/vertical axis; and (c) the slope $(\alpha)$ of the free surface (unconfined flow) is small enough than $\alpha=\sin (\alpha)$ (in radians) (e.g., [28, 37]); the flow is saturated (e.g., [34, 35]); the river fully penetrates the aquifer (e.g., [71]); the aquifer can be unconfined (e.g., [26, 30]), confined (e.g., [48]), and leaky (e.g., $[48,72]$ ). Fig. 7 shows a diagrammatic cross-section through a confined, a leaky, and an unconfined aquifer configuration. However, according to [73], some of these assumptions do not agree with the observed hydrogeological conditions. The homogeneity of the aquifer, for example, is not fulfilled since the hydraulic conductivity

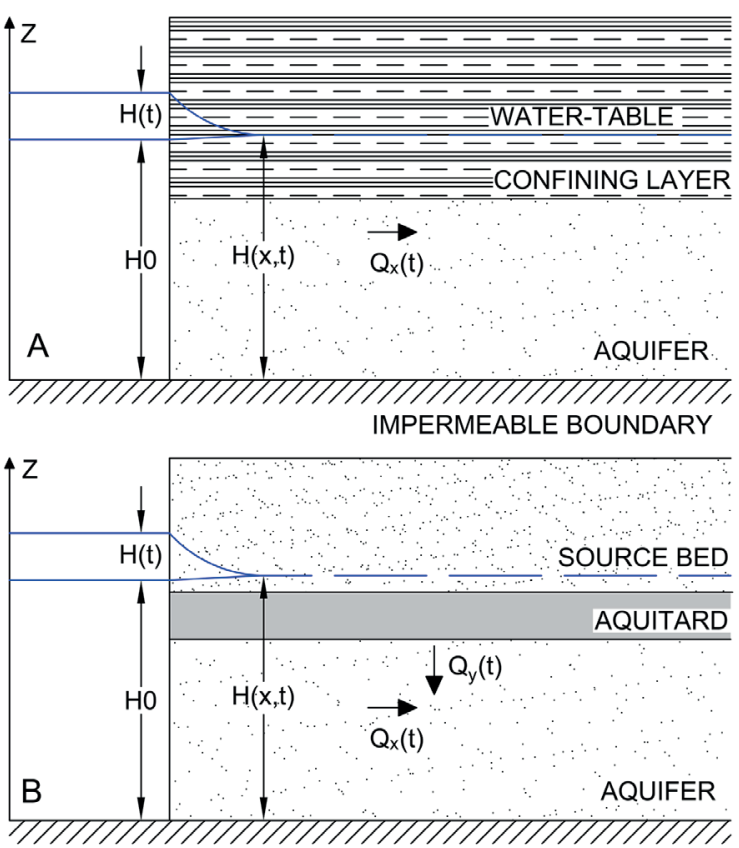

IMPERMEABLE BOUNDARY

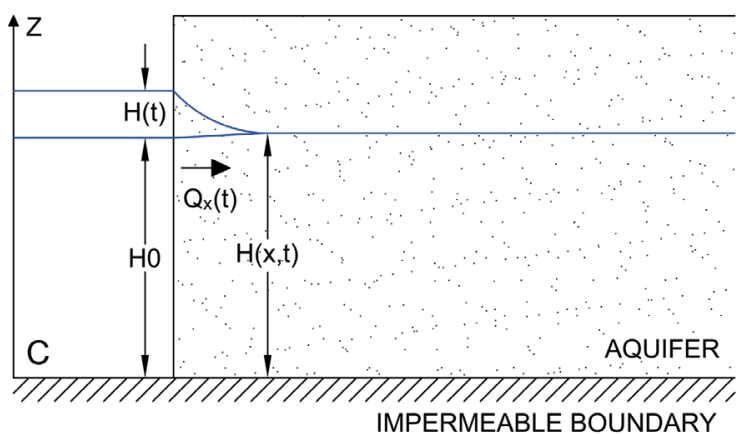

Fig. 7 (a) Semi-infinite, confined aquifer; (b) Semi-infinite, leaky aquifer with the aquitard; (c) Unconfined aquifer

increases exponentially with the depth in the main alluvial aquifers [73]. The Dupuit-Forchheimer conditions are not met because the groundwater flow is not uniform across the depth and the flow is not necessarily horizontal in the vicinity of the riverbed, for example (e.g., [14, 67, 70]). The assumption of a fully penetrating river is usually violated because most alluvial aquifers are actually partially penetrating the river (e.g., [74]). In addition, this condition leads to the invalidity of the Dupuit assumptions, which makes most one-dimensional models subject to imprecision.

Following these assumptions, many authors developed analytical solutions for river-aquifer interactions considering one-dimensional lateral groundwater flow (horizontal) in confined aquifers bounded by a river (e.g., [37, 38]). The mathematical solution proposed by [37] is based on the linearized Boussinesq equation with the DupuitForchheimer assumptions, subject to time-dependent 
boundary conditions, aiming at predicting groundwater response across a finite aquifer due to a highly fluctuating river boundary condition. The Boussinesq equation has also been employed by groundwater hydrologists to describe essentially one-dimensional horizontal flow in unconfined aquifers (e.g., [75-78]). However, it appears that linearization of the nonlinear Boussinesq equation may lead to errors, of up to $10 \%$ in terms of predictions of the maximum flow rate to the aquifer from the river, when compared to a numerical solution of the nonlinear Boussinesq equation [76]. A similar error can be seen in [37]: despite the excellent agreement between observed and simulated water levels, when a large flow event was modeled, the simulated rise in groundwater levels was not as large or did not occur as quickly as the observed data for locations close to the river.

Further, a solution to remove the error was provided by [77]. The modifications by [77] provide better results, when compared to the numerical solution, than the solutions presented by [76], especially for flows from the river to the aquifer, however, when the flow is from the aquifer to the river, more theoretical studies are needed. Moreover, they found that even if the real magnitudes of the maximum flow rate was wrong, the general shape of the curve that predicts inflow to the bank storage as a function of time was well captured by their analytical solution.

Considering a realistic field condition, where variations in river level are arbitrary over time, a convolution integral is used to describe the response of the river-aquifer system due to either an instantaneous impulse or a step unit of river-level fluctuations, recharge, or evapotranspiration. The principle of convolution, in hydrology, is the time-integrated response of a linear system (i.e., the groundwater hydrograph) to an input given by time series (the river hydrograph). Ha et al. [15], Moench et al. [25], Barlow et al. [48], Barlow and Moench [66], Moench and Barlow [69], used the convolution method combined with Laplace transform of step-response functions for several cases (confined, leaky, and water table aquifer systems). For the assumption of linearity, the hydraulic properties and material of the riverbank must remain constant over time and, for water table aquifers, the changes in the head must be small compared to the initial saturated thickness of the aquifer [48].

Although the use of one-dimensional lateral flow analytical solutions is widely used among researchers, Gill [27] attested that at small time scales, two-dimensional lateral (horizontal and vertical groundwater flow) flow solutions are necessary, since the one-dimensional solution generally gives inaccurate results, as was also stated by [73]. One of the first researchers to approach this issue was [26], who developed an analytical solution using integral techniques, applied to the case of an unsteady flow in a semi-infinite leaky aquifer and a river reach with semipermeable streambanks. Their results show that there is $60 \%$ greater bank storage when considering a permeable streambank, in other words, allowing infiltration to occur under the semipermeable layer (see model configuration for leaky aquifer in Fig. 7(b)). Neglecting the permeability of the streambank in mathematical models can lead to an overestimation of the amount of flood wave modification by bank storage, and because of that, such an assumption should not be made when analyzing aquifer-river systems, unless backed up by field evidence.

A diffusive flood wave along the river commonly occurs during floods and, consequently, river-aquifer interactions must consider not only a cross section of the river, but a longer reach, so that analytical solutions would couple the groundwater flow and open channel equations [28]. Solutions proceed in an iterative way so that in a first step, the solution of the flood wave is obtained disregarding the infiltration of the bank (similar approach was used by [25]), then, this solution is used to obtain an approximate solution of the groundwater equations, which in turn will be used to obtain a second order approximation for the flood wave solution, as stated by [28]. Another approach was provided by [30], who used discrete-time analysis of dynamic flow-aquifer interactions using the impulse-response concept and unit step response functions for linear systems. The solution considers one-dimensional lateral flow in a semi-infinite homogeneous unconfined aquifer in contact with a river with semipermeable layer. The principle of their method is the Muskigum flow routing method modified to include bank storage.

Similar conclusions were made by [9]. Their analytical model describes groundwater flow, perpendicular and parallel to the river, through a two-dimensional Boussinesq equation, and to model the flood wave, they used a diffusive-type flood wave for open channels. The results of this study showed the same conclusions as some other researchers: during the flood, the river infiltrates into the aquifer faster, and as the flood wave passes downstream in the river, most of the water infiltrated into the aquifer will return to the river shortly after the peak and the rest during a longer period of time. In addition, it was noted that, when comparing the results with the one-dimensional model 
(in the transverse plane), the hydraulic head of the aquifer was underestimated in the one-dimensional model, which can be explained by the fact that, in cross-section, the hydraulic load is not only affected by the flood wave of the river, but also influenced by the flow of the water table parallel to the river. Fig. 8 shows the model configuration for this type of problem.

Most situations in river-aquifer interaction, such as the presence of complicated boundary conditions of the aquifer, heterogeneous aquifer or complicated flow and stage relationships, are not easily addressed using analytical methods. In such cases, it may be necessary to use numerical modeling methods that combine open channel flow equations and the groundwater flow equation to simultaneously solve the river stage and the water table. Also, numerical modelling is the only general method of predictive analysis, which can be extended to arbitrary river and soil morphologies.

Pinder and Sauer [35] developed one of the first studies to couple open-channel flow and groundwater flow, and to demonstrate the modification of the flood hydrograph due to bank storage through numerical modelling. The model solves the differential equations that describe one-dimensional open channel flow (the Saint Venant equations) and groundwater flow in the wetted perimeter, by Darcy's law. The flow through the wetted perimeter of the channel is a function of the water level of the aquifer and the water level of the river. The calculation of the water level of the aquifer is carried out by means of a mathematical simulation of the transient horizontal one-dimensional unconfined groundwater flow. The problem demonstrates the response of the river-aquifer system to the propagation of a flood wave along a river hydraulically connected to a floodplain aquifer and having no lateral inflow over the riverbanks or tributaries. The results may indicate the importance of bank storage in the formation of the river's hydrograph, delaying the arrival of the flood wave and decreasing the peak of the flood, where in this particular problem, the flow hydrograph ends up being much smaller in a section approximately 27 kilometers downstream.

Since then, several authors have been developing and applying numerical solutions to real cases. For example, one of the most common models used is MODFLOW, a transient three-dimensional groundwater flow model, developed by [32]. Squillace [36] constructed a two-dimensional model of groundwater flow through MODFLOW at the Palisades study site, located in a part of the Cedar River floodplain (Iowa). The objective of the study was to
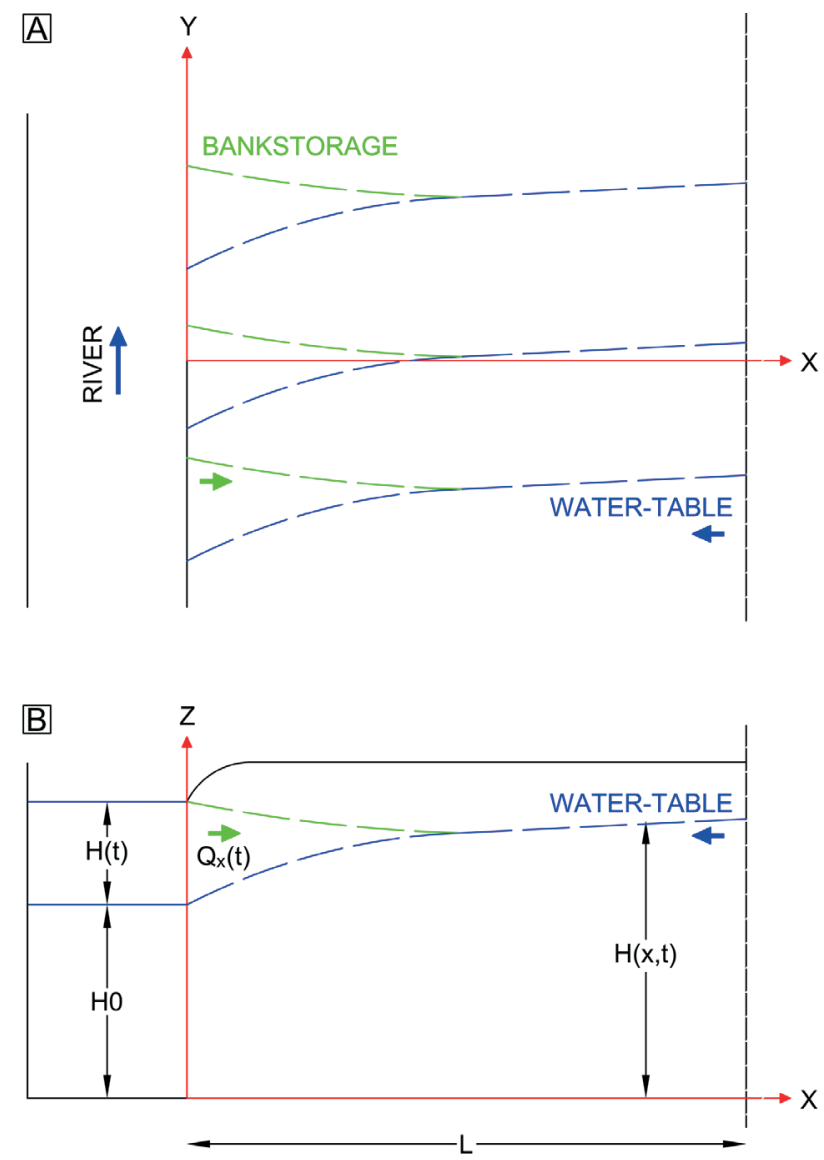

Fig. 8 (a) plan model configuration of groundwater flow to/from a river, with Y-axis parallel to the river flow, and the X-axis perpendicular to the river, dashed lines denote groundwater elevation contours at mean (blue) and high (green) river stage; (b) cross-sectional profile of groundwater flow to/from a river $(\mathrm{z}-\mathrm{x})$, the surface water level $(\mathrm{H}(\mathrm{t}))$ varying as a function of time $(t)$, and the aquifer head $(H(x, t))$ varying as a function of the distance from the river $(\mathrm{x})$ and time $(\mathrm{t})$

quantify the movement of bank storage. The simulations showed that an increase of $2 \mathrm{~m}$ in the river level caused the bank storage volume to move $30 \mathrm{~m}$ horizontally and $4 \mathrm{~m}$ vertically below the river bottom, which is equivalent to $70 \%$ of bank storage volume moved under the riverbed and $30 \%$ moved laterally to the riverbanks. Thus, the bottom part of the bank storage volume can be significant in wide and shallow rivers because the river's width is much greater than its depth. Therefore, even in narrow rivers like the Cedar River, bottom storage can be significant.

The problem with using generic models, such as MODFLOW, to simulate river-aquifer interactions is that a general assumption of a rectangular channel with vertical banks is assumed, and the flow passes through the channel bed. However, it is possible to model channels with sloping banks by creating a stepped river profile with fine localized discretization, or by using a depth-dependent conductance 
term, which can be possible with the MODFLOW SFR2 package, for example. Doble et al. [67] explore the implications of assuming a vertical riverbank and saturated flow for calculating bank storage and return flows. A fully coupled surface-subsurface flow model (HydroGeoSphere) was used to perform numerical simulations in river-aquifer cross sections with vertical and inclined river boundaries [67]. The model simultaneously solves the approximation of the diffusion wave from the two-dimensional shallow water equations to the surface water flow and the transient three-dimensional variably saturated groundwater flow through the Richards' equation [79]. Validation of the model can be seen in the paper by [80] in two-dimensional disconnected river-aquifer system problem, and in the study of [71], who simulated solute transport due to river-aquifer interactions. According to [67], sloping riverbanks have been found to increase infiltration rates by a significant $98 \%$ and bank storage volume by $40 \%$ compared to vertical riverbanks and the saturated flow, delaying the bank's return flow more than four times. The results suggested that conventional analytical approaches cannot be used to properly quantify the bank storage when the bank slope is less than $60^{\circ}$ from the horizontal, which is the most common scenario.

It was demonstrated that simplifications by the Dupuit assumptions do not represent situations in which changes in the flow into or out of the river occur quickly and the water-table close to the banks is highly inclined. Instead, Whiting and Pomeranets [14] developed a model that describes the unsteady flow of saturated unconfined aquifer, interfacing the river with a free movement boundary condition, using governing equations based on the previous work of Neuman and Witherspoon [39, 81, 82]. The model, called WaTAb2D, can be used in general twodimensional (in a plane perpendicular to the river) cases: non-symmetrical valleys, non-symmetrical channels, non-uniform hydraulic conductivity, and non-stationary boundary flows. Results regarding the release from bank storage could be compared with those of [12], concluding that the discharge rate is large initially and then drops drastically to asymptotically approach zero discharge, after a flood-wave period.

Overbank flood modeling received little attention compared to field studies. Workman and Serrano [83] calculated overbank recharge from floods through the difference between observed water-table levels and water-table levels simulated through modelling, however a dynamic width was not accounted in this work. The results showed that, over a five-year monitoring period, the direct recharge associated with the two flood events was responsible for 65 percent of the total calculated recharge. Similarly, a methodology presented by [42] aims to estimate the aquifer recharge from floods events (in-bank) in disconnected river-aquifer systems. Floods in disconnected rivers may cause larger net recharge because return flow to the river does not occur and the low permeability layer at the streambed is temporarily removed. Doble et al. [84] examined the physics governing the process of overbank flooding and investigated a simplified approach for estimating overbank flood recharge through the floodplain, however, their study did not include bank storage component. Additionally, they suggest that a finer resolution of the Digital Elevation Models (DEMs) can provide more accurate results of the recharge through the floodplain, since the topography can affect the impacts of the flood duration [84]. Wang et al. [65] analyzed changes in the depth and quality of a regional shallow aquifer in the Sanjiang Plain, Northeast China, following a large flood in the summer of 2013. The study found that the flood not only played a tremendous recharging role for the regional groundwater storage, but also changed the water quality.

Few studies considered the flux of water to and from surrounding hillslopes associated with flood events. Bates et al. [10] developed a numerical model to determine the effects of water fluxes to and from hillslopes on the response of the floodplain and examined hydrological processes occurring during large out-of-bank flood events. The two-dimensional finite element model, ESTEL [85], can represent saturated and unsaturated flow in vertically cross sections through the hillslope/floodplain/channel continuum within a small section of the River Severn floodplain in the United Kingdom. Like WaTab2D [14], ESTEL model is also based on an exact formulation for time-dependent unconfined groundwater flow, but unlike the WaTab2D model, the ESTEL model applies to both saturated and unsaturated flow conditions. Flow under unsaturated conditions can also be simulated through the Unsaturated-Zone Flow package of the MODFLOW [40].

Although several numerical modeling studies have been applied to specifically investigate the interaction of surface and groundwater during flood events, most of them ignore the heterogeneity of the bank's soil. Berg et al. [86] calibrates a fully integrated, site-specific surface and subsurface model (Hydrogeosphere) using flood events for the South River near Waynesboro, VA. The calibration approach presented in their study incorporates a highly parametrized 
model domain, containing different soil properties, with depositional environmental attributes (e.g., grain refinement direction) and driven by a flood hydrograph, to develop several realistic realizations of hydraulic conductivity fields that reflect historical depositional system.

\section{Conclusions}

The interaction between surface and groundwater has been the focus of a great number of studies and review articles, reflected in the long list of references in this paper.

The amount of bank storage - volume of surface water stored in the riverbanks - during a fluvial flood depends on parameters such as duration, height, and shape of the flood hydrograph, as well as the transmissivity and storage capacity of the aquifer. In general, a longer flood, higher aquifer diffusivity and transmissivity result in greater bank storage, so rivers with a coarse alluvium have a greater storage capacity of the aquifer.

The aquifer's properties must be determined by means of measurements or inverse modeling, as the cited studies point out. The choice of the appropriate method of field measurement will depend on the objective of the study, as well as on its spatial and temporal scale. For a small spatial scale, methods such as infiltration meters, "mini piezometers" or hydraulic potentiometers, may be the most suitable, but on a larger scale, surface flow modeling, groundwater flow modeling and flow network analysis are often more appropriate. One of the challenges is that groundwater and surface water levels provided by routine monitoring gauges typically provide only coarse data during flood events.

Mathematical modeling is the universal method of analysis for river-aquifer exchanges and bank storage during extreme events. Analytical and numerical solutions seek to represent real cases, defining specific assumptions and boundary conditions. Some of these assumptions produce unrealistic results stemming from their simplicity. For example, Dupuit's widely adopted assumption in analytical models, which assumes that groundwater flow is horizontal and uniform along the depth, is usually violated in the vicinity of the riverbed, on leaky aquifers and across

\section{References}

[1] Winter, T. C., Harvey, J. W., Franke, O. L., Alley, W. M. "Ground water and surface water: A single resource", Circular, U.S. Geological Survey, Denver, CO, USA, Rep. 1139, 1998.

https://doi.org/10.3133/cir1139

[2] Woessner, W. W. "Stream and Fluvial Plain Ground Water Interactions: Rescaling Hydrogeologic Thought", Groundwater, 38(3), pp. 423-429, 2000.

https://doi.org/10.1111/j.1745-6584.2000.tb00228.x a flooded floodplain, resulting in a poor estimation of the boundary processes.

As for bank storage due to overbank floods, its modeling received little attention compared to field studies. Reducing the problem to the transverse plane is attractive but it disregards that flood waves are diffusive along the river. Because of that, analytical and numerical solutions of river-aquifer interactions should consider a longer reach, coupling groundwater and open channel flows equations, resolving groundwater flow parallel to the river.

The theoretical results and practical studies related to general observations summarized in this paper will assist an engineer in selecting the correct methods for analyzing and quantifying surface and groundwater during flood events.

One must pay attention to the particularities of the case to be studied, such as the morphology of the river soil and the floodplain, topography, and aquifer properties. Widely used simplifications, such as assuming the Dupuit condition or a rectangular river section, for example, often present satisfactory results with respect to maximum infiltration flow rates, but can still give a poor estimate of bank storage, as shown in the review presented here.

It is recommended to use more complex numerical models, which include flood wave simulations in the river, and infiltration of the surface water into the riverbanks and across the floodplain simultaneously to solve problems of river-aquifer interactions during extreme flood events. Additionally, with the advance of technology based on newly opening possibilities and the increase in computational power tools (e.g., artificial intelligence in analyzing huge data, remote sensing, rapid development, and calibration of site-specific models), modeling and data acquisition practices can be facilitated, achieving closer results to the reality.

\section{Acknowledgement}

The research reported in this paper and carried out at BME has been supported by the NRDI Fund TKP2021 BME-NVA. In addition G. Ferraz's research is supported by the Stipendium Hungaricum scholarship.

[3] Sophocleous, M. "Interactions between groundwater and surface water: the state of the science", Hydrogeology Journal, 10, pp. 52-67, 2002.

https://doi.org/10.1007/s10040-001-0170-8

[4] Brunke, M., Gonser, T. "The ecological significance of exchange processes between rivers and groundwater", Freshwater Biology, 37(1), pp. 1-33, 1997.

https://doi.org/10.1046/j.1365-2427.1997.00143.x 
[5] Cranswick, R. H., Cook, P. G. "Scales and magnitude of hyporheic, river-aquifer and bank storage exchange fluxes", Hydrological Processes, 29(14), pp. 3084-3097, 2015.

https://oi.org/10.1002/hyp.10421

[6] Bencala, K. E., Gooseff, M. N., Kimball, B. A. "Rethinking hyporheic flow and transient storage to advance understanding of stream-catchment connections", Water Resources Research, 47(3), Article ID W00H03, 2011.

https://oi.org/10.1029/2010WR010066

[7] Lewandowski, J., Arnon, S., Banks, E., Batelaan, O., Betterle, A., Broecker, T., Coll, C., Drummond, J.D., Gaona Garcia, J., Galloway, J., ..., Wu, L. "Is the Hyporheic Zone Relevant beyond the Scientific Community?", Water, 11(11), Article number: 2230, 2019.

https://doi.org/10.3390/w11112230

[8] Wroblicky, G. J., Campana, M. E., Valett, H. M., Dahm, C. N. "Seasonal variation in surface-subsurface water exchange and lateral hyporheic area of two stream-aquifer systems", Water Resources Research, 34(3), pp. 317-328, 1998.

https://doi.org/10.1029/97WR03285

[9] Liang, X., Zhan, H., Schilling, K. "Spatiotemporal responses of groundwater flow and aquifer-river exchanges to flood events", Water Resources Research, 54(3), pp. 1513-1532, 2018. https://doi.org/10.1002/2017WR022046

[10] Bates, P. D., Stewart, M. D., Desitter, A., Anderson, M. G., Renauad, J.-P., Smith, J. A. "Numerical simulation of floodplain hydrology", Water Resources Research, 36(9), pp. 2517-2529, 2000. https://doi.org/10.1029/2000WR900102

[11] Claxton, A. J., Bates, P. D., Cloke, H. L. "Mixing of Hillslope, River, and Alluvial Ground Waters in Lowland Floodplains", Groundwater, 41(7), pp. 926-936, 2003. https://doi.org/10.1111/j.1745-6584.2003.tb02435.x

[12] Cooper, H. H., Rorabaugh, M. I. "Ground-water movements and bank storage due to flood stages in surface streams", Water Supply Paper, U.S. Government Printing Office, Reston, VA, USA, Rep. 1536-J, 1963.

https://doi.org/10.3133/wsp1536J

[13] Kondolf, G. M., Maloney, L. M., Williams, J. G. "Effects of bank storage and well pumping on base flow, Carmel River, Monterey County, California", Journal of Hydrology, 91, pp. 351-369, 1987. https://doi.org/10.1016/0022-1694(87)90211-3

[14] Whiting, P. J., Pomeranets, M. "A numerical study of bank storage and its contribution to streamflow", Journal of Hydrology, 202(1-4), pp. 121-136, 1997. https://doi.org/10.1016/S0022-1694(97)00064-4

[15] Ha, K., Koh, D.-C., Yum, B.-W., Lee, K.-K. "Estimation of river stage effect on groundwater level, discharge, and bank storage and its field application", Geosciences Journal, 12, pp. 191-204, 2008. https://doi.org/10.1007/s12303-008-0020-y

[16] Chen, X., Chen, X. "Stream water infiltration, bank storage, and storage zone changes due to stream-stage fluctuations", Journal of Hydrology, 280(1-4), pp. 246-264, 2003. https://doi.org/10.1016/S0022-1694(03)00232-4

[17] Kalbus, E., Reinstorf, F., Schirmer, M. "Measuring methods for groundwater-surface water interactions: a review", Hydrology and Earth System Sciences, 10(6), pp. 873-887, 2006.

https://doi.org/10.5194/hess-10-873-2006
[18] Rosenberry, D. O., LaBaugh, J. W. "Field Techniques for Estimating Water Fluxes Between Surface Water and Ground Water", Techniques and Methods, U.S. Geological Survey, Reston, VA, USA, Rep. 4-D2, 2008 https://doi.org/10.3133/tm4D2

[19] Divine, C. E., McDonnell, J. J. "The future of applied tracers in hydrogeology", Hydrogeology Journal, 13(1), pp. 255-258, 2005. https://doi.org/10.1007/s10040-004-0416-3

[20] Fanelli, R. M., Lautz, L. K. "Patterns of Water, Heat, and Solute Flux through Streambeds around Small Dams", Groundwater, 46(5), pp. 671-687, 2008. https://doi.org/10.1111/j.1745-6584.2008.00461.x

[21] Harvey, J. W., Bencala, K. E. "The effect of streambed topography on surface-subsurface water exchange in mountain catchments", Water Resources Research, 29(1), pp. 89-98, 1993. https://doi.org/10.1029/92WR01960

[22] Batlle-Aguilar, J., Harrington, G. A., Leblanc, M., Welch, C., Cook, P. G. "Chemistry of groundwater discharge inferred from longitudinal river sampling", Water Resources Research, 50(2), pp. 1550$1568,2014$. https://doi.org/10.1002/2013WR013591

[23] Solomon, D. K., Genereux, D. P., Plummer, L. N., Busenberg, E. "Testing mixing models of old and young groundwater in a tropical lowland rain forest with environmental tracers", Water Resources Research, 46(4), 2010 https://doi.org/10.1029/2009WR008341

[24] Smerdon, B. D., Gardner, W. P., Harrington, G. A., Tickell, S. J. "Identifying the contribution of regional groundwater to the baseflow of a tropical river (Daly River, Australia)", Journal of Hydrology, 464-465, pp. 107-115, 2012. https://doi.org/10.1016/j.jhydrol.2012.06.058

[25] Moench, A. F., Sauer, V. B., Jennings, M. E. "Modification of routed streamflow by channel loss and base flow", Water Resources Research, 10(5), pp. 963-968, 1974. https://doi.org/10.1029/WR010i005p00963

[26] Dever, Jr, R. J., Cleary, R. W. "Unsteady-state, two-dimensional response of leaky aquifers to stream stage fluctuations", Advances in Water Resources, 2, pp. 13-18, 1979. https://doi.org/10.1016/0309-1708(79)90002-2

[27] Gill, M. A. "Bank storage characteristics of a finite aquifer due to sudden rise and fall of river level", Journal of Hydrology, 76(1-2), pp. 133-142, 1985. https://doi.org/10.1016/0022-1694(85)90094-0

[28] Hunt, B. "An Approximation for the Bank Storage Effect", Water Resources Research, 26(11), pp. 2769-2775, 1990. https://doi.org/10.1029/WR026i011p02769

[29] Hatch, C. E., Fisher, A. T., Ruehl, C. R., Stemler, G. "Spatial and temporal variations in streambed hydraulic conductivity quantified with time-series thermal methods", Journal of Hydrology, 389(3-4), pp. 276-288, 2010 https://doi.org/10.1016/j.jhydrol.2010.05.046

[30] Hantush, M. M., Harada, M., Mariño, M. A. "Hydraulics of Stream Flow Routing with Bank Storage", Journal of Hydrologic Engineering, 7(1), pp. 76-89, 2002 https://doi.org/10.1061/(ASCE)1084-0699(2002)7:1(76) 
[31] Grapes, T. R., Bradley, C., Petts, G. E. "Hydrodynamics of floodplain wetlands in a chalk catchment: The River Lambourn, UK", Journal of Hydrology, 320(3-4), pp. 324-341, 2006. https://doi.org/10.1016/j.jhydrol.2005.07.028

[32] McDonald, M. G., Harbaugh, A. W. "A modular three-dimensional finite-difference ground-water flow model", Open-File Report, US Geological Survey, Reston, VA, USA., Rep. 83-875, 1988. https://doi.org/10.3133/ofr83875

[33] Wondzell, S. M., Swanson, F. J. "Floods, channel change, and the hyporheic zone", Water Resources Research, 35(2), pp. 555-567, 1999.

https://doi.org/10.1029/1998WR900047

[34] Li, H., Boufadel, M. C., Weaver, J. W. "Quantifying Bank Storage of Variably Saturated Aquifers", Groundwater, 46(6), pp. 841-850, 2008. https://doi.org/10.1111/j.1745-6584.2008.00475.x

[35] Pinder, G. F., Sauer, S. P. "Numerical simulation of flood wave modification due to bank storage effects", Water Resources Research, 7(1), pp. 63-70, 1971. https://doi.org/10.1029/WR007i001p00063

[36] Squillace, P. J. "Observed and Simulated Movement of BankStorage Water", Groundwater, 34(1), pp. 121-134, 1996. https://doi.org/10.1111/j.1745-6584.1996.tb01872.x

[37] Workman, S. R., Serrano, S. E. "Recharge to alluvial valley aquifers from overbank flow and excess infiltration", JAWRA Journal of the American Water Resources Association, 35(2), pp. 425-432, 1999. https://doi.org/10.1111/j.1752-1688.1999.tb03600.x

[38] Boufadel, M. C., Peridier, V. "Exact analytical expressions for the piezometric profile and water exchange between stream and groundwater during and after a uniform rise of the stream level", Water Resources Research, 38(7), pp. 27-1-27-6, 2002. https://doi.org/10.1029/2001WR000780

[39] Neuman, S. P., Witherspoon, P. A. "Finite Element Method of Analyzing Steady Seepage with a Free Surface", Water Resources Research, 6(3), pp. 889-897, 1970. https://doi.org/10.1029/WR006i003p00889

[40] Niswonger, R. G., Prudic, D. E., Regan, R. S. "Documentation of the Unsaturated-Zone Flow (UZF1) Package for modeling unsaturated flow between the land surface and the water table with MODFLOW-2005", [pdf] U.S. Geological Survey, Reston, VA, USA, 2006, Available at: https://pubs.usgs.gov/tm/2006/tm6a19/ pdf/tm6a19.pdf [Accessed: 20 May 2021]

[41] Rutschmann, P., Hager, W. H. "Diffusion of floodwaves", Journal of Hydrology, 178(1-4), pp. 19-32, 1996. https://doi.org/10.1016/0022-1694(95)02824-2

[42] Vázquez-Suñé, E., Capino, B., Abarca, E., Carrera, J. "Estimation of Recharge from Floods in Disconnected Stream-Aquifer Systems", Groundwater, 45(5), pp. 579-589, 2007. https://doi.org/10.1111/j.1745-6584.2007.00326.x

[43] Stephens, D. B. "Vadose Zone Hydrology", CRC press, Boca Raton, FL, USA, 1995.

[44] Gordon, N. D., McMahon, T. A., Finlayson, B. L., Gippel, C. J., Nathan, R. J. "Stream hydrology: an introduction for ecologists", John Wiley and Sons, City, Country, 2004.
[45] Zimmer, M. A., McGlynn, B. L. "Bidirectional stream-groundwater flow in response to ephemeral and intermittent streamflow and groundwater seasonality", Hydrological Processes, 31(22), pp. 3871-3880, 2017. https://doi.org/10.1002/hyp.11301

[46] Vogt, T., Hoehn, E., Schneider, P., Freund, A., Schirmer, M., Cirpka, O. A. "Fluctuations of electrical conductivity as a natural tracer for bank filtration in a losing stream", Advances in Water Resources, 33(11), pp. 1296-1308, 2010.

https://doi.org/10.1016/j.advwatres.2010.02.007

[47] Sprenger, C., Lorenzen, G., Hülshoff, I., Grützmacher, G., Ronghang, M., Pekdeger, A. "Vulnerability of bank filtration systems to climate change", Science of the Total Environment, 409(4), pp. 655-663, 2011.

https://doi.org/10.1016/j.scitotenv.2010.11.002

[48] Barlow, P. M., DeSimone, L. A., Moench, A. F. "Aquifer response to stream-stage and recharge variations. II. Convolution method and applications", Journal of Hydrology, 230(3-4), pp. 211-229, 2000. https://doi.org/10.1016/S0022-1694(00)00176-1

[49] Welch, C., Cook, P. G., Harrington, G. A., Robinson, N. I. "Propagation of solutes and pressure into aquifers following river stage rise", Water Resources Research, 49(9), pp. 5246-5259, 2013. https://doi.org/10.1002/wrcr.20408

[50] Cook, P. G. "Estimating groundwater discharge to rivers from river chemistry surveys", Hydrological Processes, 27(25), pp. 3694-3707, 2013.

https://doi.org/10.1002/hyp.9493

[51] Gianni, G., Richon, J., Perrochet, P., Vogel, A., Brunner, P. "Rapid identification of transience in streambed conductance by inversion of floodwave responses", Water Resources Research, 52(4), pp. 2647-2658, 2016. https://doi.org/10.1002/2015WR017154

[52] Lewandowski, J., Lischeid, G., Nützmann, G. "Drivers of water level fluctuations and hydrological exchange between groundwater and surface water at the lowland River Spree (Germany): field study and statistical analyses", Hydrological Processes, 23(15), pp. 2117-2128, 2009.

https://doi.org/10.1002/hyp.7277

[53] Calver, A. "Riverbed Permeabilities: Information from Pooled Data", Groundwater, 39(4), pp. 546-553, 2001. https://doi.org/10.1111/j.1745-6584.2001.tb02343.x

[54] Bailly-Comte, V., Borrell-Estupina, H., Jourde, H., Pistre, S. "A conceptual semidistributed model of the Coulazou River as a tool for assessing surface water-karst groundwater interactions during flood in Mediterranean ephemeral rivers", Water Resources Research, 48(9), 2012.

https://doi.org/10.1029/2010WR010072

[55] Isiorho, S. A., Meyer, J. H. "The Effects of Bag Type and Meter Size on Seepage Meter Measurements", Groundwater, 37(3), pp. 411-413, 1999. https://doi.org/10.1111/j.1745-6584.1999.tb01119.x

[56] Hunter, N. M., Bates, P. D., Horritt, M. S., Wilson, M. D. "Simple spatially-distributed models for predicting flood inundation: A review", Geomorphology, 90(3-4), pp. 208-225, 2007. https://doi.org/10.1016/j.geomorph.2006.10.021 
[57] Sophocleous, M. A. "Stream-floodwave propagation through the Great Bend alluvial aquifer, Kansas: field measurements and numerical simulations", Journal of Hydrology, 124(3-4), pp. 207-228, 1991.

https://doi.org/10.1016/0022-1694(91)90015-A

[58] Vekerdy, Z., Meijerink, A. M. J. "Statistical and analytical study of the propagation of flood-induced groundwater rise in an alluvial aquifer", Journal of Hydrology, 205(1-2), pp. 112-125, 1998. https://doi.org/10.1016/S0022-1694(97)00148-0

[59] McCallum, J. L., Cook, P. G., Berhane, D., Rumpf, C., McMahon, G. A. "Quantifying groundwater flows to streams using differential flow gaugings and water chemistry", Journal of Hydrology, 416417, pp. 118-132, 2012. https://doi.org/10.1016/j.jhydrol.2011.11.040

[60] Csoma, R., Gálos, M. "River - Groundwater Interaction over the Region of INFOPARK-Budapest", Periodica Polytechnica Civil Engineering, 56(2), pp. 221-232, 2012. https://doi.org/10.3311/pp.ci.2012-2.08

[61] Cranswick, R. H., Cook, P. G., Lamontagne, S. "Hyporheic zone exchange fluxes and residence times inferred from riverbed temperature and radon data", Journal of Hydrology, 519(B), pp. 18701881, 2014.

https://doi.org/10.1016/j.jhydrol.2014.09.059

[62] Hester, E. T., Guth, C. R., Scott, D. T., Jones, C. N. "Vertical surface water-groundwater exchange processes within a headwater floodplain induced by experimental floods", Hydrological Processes, 30(21), pp. 3770-3787, 2016.

https://doi.org/10.1002/hyp.10884

[63] Barlow, J. R. B., Coupe, R. H. "Use of heat to estimate streambed fluxes during extreme hydrologic events", Water Resources Research, 45(1), 2009. https://doi.org/10.1029/2007WR006121

[64] Jung, M., Burt, T. P., Bates, P. D. "Toward a conceptual model of floodplain water table response", Water Resources Research, 40(12), 2004.

https://doi.org/10.1029/2003WR002619

[65] Wang, X., Zhang, G., Xu, Y. J. "Impacts of the 2013 Extreme Flood in Northeast China on Regional Groundwater Depth and Quality", Water, 7(8), pp. 4575-4592, 2015. https://doi.org/10.3390/w7084575

[66] Barlow, P. M., Moench, A. F. "Analytical solutions and computer programs for hydraulic interaction of stream-aquifer systems", U.S. US Geological Survey, Reston, VA, USA, Rep. 98-415, 1998. https://doi.org/10.3133/ofr98415A

[67] Doble, R., Brunner, P., McCallum, J., Cook, P. G. "An Analysis of River Bank Slope and Unsaturated Flow Effects on Bank Storage", Groundwater, 50(1), pp. 77-86, 2012. https://doi.org/10.1111/j.1745-6584.2011.00821.x

[68] Cloutier, C.-A., Buffin-Bélanger, T., Larocque, M. "Controls of groundwater floodwave propagation in a gravelly floodplain", Journal of Hydrology, 511, pp. 423-431, 2014. https://doi.org/10.1016/j.jhydrol.2014.02.014

[69] Moench, A. F., Barlow, P. M. "Aquifer response to stream-stage and recharge variations. I. Analytical step-response functions", Journal of Hydrology, 230(3-4), pp. 192-210, 2000.

https://doi.org/10.1016/S0022-1694(00)00175-X
[70] Hunt, B. "Bank-storage problem and the Dupuit approximation", Journal of Hydrologic Engineering, 10(2), pp. 118-124, 2005. https://doi.org/10.1061/(ASCE)1084-0699(2005)10:2(118)

[71] McCallum, J. L., Cook, P. G., Brunner, P., Berhane, D. "Solute dynamics during bank storage flows and implications for chemical base flow separation", Water Resources Research, 46(7), 2010. https://doi.org/10.1029/2009WR008539

[72] Rushton, K. R., Tomlinson, L. M. "Possible mechanisms for leakage between aquifers and rivers", Journal of Hydrology, 40(1-2), pp. 49-65, 1979. https://doi.org/10.1016/0022-1694(79)90087-8

[73] Sharp, Jr, J. M. "Limitations of bank-storage model assumptions", Journal of Hydrology, 35(1-2), pp. 31-47, 1977. https://doi.org/10.1016/0022-1694(77)90075-0

[74] Huang, Y., Zhou, Z. F., Yu, Z. B. "Analytical solution based on stream-aquifer interactions in partially penetrating streams", Water Science and Engineering, 3(3), pp. 292-303, 2010. https://doi.org/10.3882/j.issn.1674-2370.2010.03.005

[75] Hantush, M. M. "Modeling stream-aquifer interactions with linear response functions", Journal of Hydrology, 311, pp. 59-79, 2005. https://doi.org/10.1016/j.jhydrol.2005.01.007

[76] Govindaraju, R. S., Koelliker, J. K. "Applicability of linearized Boussinesq equation for modeling bank storage under uncertain aquifer parameters", Journal of Hydrology, 157, pp. 349-356, 1994. https://doi.org/10.1016/0022-1694(94)90113-9

[77] Hogarth, W. L., Govindaraju, R. S., Parlange, J. Y., Koelliker, J. K. "Linearised Boussinesq equation for modelling bank storage - a correction", Journal of Hydrology, 198(1-4), pp. 377-385, 1997. https://doi.org/10.1016/S0022-1694(96)03208-8

[78] Serrano, S. E., Workman, S. R. "Modeling transient stream/aquifer interaction with the non-linear Boussinesq equation and its analytical solution", Journal of Hydrology, 206(3-4), pp. 245-255, 1998. https://doi.org/10.1016/S0022-1694(98)00111-5

[79] Therrien, R., McLaren, R. G., Sudicky, E. A., Panday, S. M. "HydroGeoSphere: A three-dimensional numerical model describing fully-integrated subsurface and surface flow and solute transport", [pdf] Groundwater Simulations Group, University of Waterloo, Waterloo, ON, Canada, 2010. Available at: https://www. ggl.ulaval.ca/fileadmin/ggl/documents/rtherrien/hydrogeosphere. pdf [Accessed: 06 May 2021]

[80] Brunner, P., Cook, P. G., Simmons, C. T. "Hydrogeologic controls on disconnection between surface water and groundwater", Water Resources Research, 45(1), 2009. https://doi.org/10.1029/2008WR006953

[81] Neuman, S. P., Witherspoon, P. A. "Variational principles for confined and unconfined flow of ground water", Water Resources Research, 6(5), pp. 1376-1382, 1970. https://doi.org/10.1029/WR006i005p01376

[82] Neuman, S. P., Witherspoon, P. A. "Analysis of Nonsteady Flow with a Free Surface Using the Finite Element Method", Water Resources Research, 7(3), pp. 611-623, 1971. https://doi.org/10.1029/WR007i003p00611

[83] Workman, S. R., Serrano, S. E., Liberty, K. "Development and application of an analytical model of stream/aquifer interaction", Journal of Hydrology, 200(1-4), pp. 149-163, 1997. https://doi.org/10.1016/S0022-1694(97)00014-0 
[84] Doble, R.C., Crosbie, R.S., Smerdon, B.D., Peeters, L., Cook, F.J. "Groundwater recharge from overbank floods", Water Resources Research, 48(9), 2012.

https://doi.org/10.1029/2011WR011441

[85] Desitter, A., Bates, P. D., Anderson, M. G., Hervouet, J.-M. "Development of one, two and three-dimensional finite element groundwater models within a generalized object-oriented framework", Hydrological Processes, 14(13), pp. 2245-2259, 2000.

https://doi.org/10.1002/1099-1085(200009)14:13\%3C2245::AIDHYP26\%3E3.0.CO;2-Q
[86] Berg, S. J., Grosso, N. R., Sherrier, M. P., Mudrick, K., Ohr, M., Hwang, H.-T., Park, Y.-J., Callaghan, M. V., Frey, S. K., Sudicky, E. A. "Natural Stimuli Calibration with Fining Direction Regularization in an Integrated Hydrologic Model", Groundwater, 57(1), pp. 21-35, 2019.

https://oi.org/10.1111/gwat.12842 